\title{
Wole Soyinka's The Road as an intertext
}

Studies on African drama have shown the influences and the intertextual relations between African drama and European (Classical and Elizabethan) plays. It is also a known fact that African drama exhibits traces of African tradition and instances of textual relations with already existing oral and written texts. However, existing studies on Wole Soyinka's The Road have tilted towards the usual literary interpretation or as a piece of theatrical performance with little attention paid to the intertextual nature of the text. Based on the challenges of these usual approaches to the study of literature by contemporary literary and cultural theories, this study adopts intertextual theory as a framework to examine Wole Soyinka's The Road as an intertext showing traces of textual influences from oral and written external sources. The aim is to reveal the source texts from which the playwright draws in the creation of the text and to show how these sources contribute to the overall thematic significance of the play. Findings reveal that Soyinka draws extensively from Yorùbá oral sacred texts, the Bible, and his own earlier texts and that these sources contribute to the eclectic nature of the thematic preoccupation of the play. It is hoped that this has gone a long way to mitigate the obscure claim of structural and thematic incomprehensibility with which the play is associated. Keywords: The Road, intertextual relations, thematic significance, Wole Soyinka

\section{Introduction}

Wole Soyinka, poet, dramatist, and novelist is one of the most prolific playwrights in the annals of Nigerian literature in particular and African literature in general. As a dramatist, his serious work in the theatre started between 1957 and 1959 when he was attached to the Royal Court Theatre, London, as a play reader. His return to Nigeria in 1960 marked a significant development in the history of Nigerian drama because, prior to this period, there was no tradition in Nigerian drama in the English language. Soyinka has written over thirty plays and his plays have received attention both from scholars and in the theatre. Whether in drama as a text or in the field of theatre, Soyinka remains unequalled in the history of modern African drama. His play, The Road, has been adjudged as one of his most exciting and problematic plays (Izevbaye 52). It is also one of his most widely discussed plays (see Ògúnba; Jones; Ogude; Katrak; Jeyifo; Maledo; Shamsi, Faghfori, and Booryazadeh; and Pouille; among others). A brief overview of his biography is important in a discussion of intertextuality in one of his most significant plays, The Road.

Born on 13 July 1934, in Ijubu Isara, Soyinka is the son of Ayo and Eniola Soyinka who were Christian converts. His biography and influences must begin with his Yorùbá heritage, his rootedness in Yorùbá culture, cosmology, and worldview. The Yorùbá are one of Africa's most culture-conscious ethnic groups in Nigeria. Traditional Yorùbá life is dominated by religion with their belief in the existence of the gods, spirits, and ancestors. In fact, the Yorùbá are said to have about four hundred and one gods (Jones 20). Among these are Olodumare, the supreme god; Òrị̀àńlá; Ėșù, a trickster god; Sango, god of thunder and lightning; Obàtálá; and Soyinka’s

Richard Oliseyenum Maledo is a lecturer in the Department of English and Literary Studies, Delta State University, Abraka, Nigeria. His research focuses in English linguistics and literary stylistics.

Email: omaledo@gmail.com

(D) https://orcid.org/0000-0002-9347-6619

Emmanuel Ogheneakpobor Emama teaches in the Department of English and Literary Studies, Delta State University, Abraka, Nigeria. He is interested in the sociolinguistics of English and the New Englishes.

Email: emama73@gmail.com

(D) https://orcid.org/0000-0001-7690-0812

DOl: https://doi.org/10.17159/tt.v57i2.6617

DATES:

Submitted: 16 July 2019; Accepted: 22 August 2019 Published: 22 July 2020 
favourite god, Ògún, which he describes as a creative and a destructive god in Myth, Literature and the African World (1976). These gods are worshipped through the Egúngún (a masquerade which also functions as the spirit of the ancestors in Yorùbá cosmology during festivals and ceremonies). Coupled with Soyinka's belief in gods is also his belief in the African cyclic view of life from the living, the dead, and the unborn. All these have an overwhelming influence on Soyinka as a literary artist and they manifest in his writings.

Equally, his Western education and early contact with the Christian religion influenced him in no small measure. He attended a missionary school of which his father was the headmaster, thus, his introduction to Christian beliefs during his youth and early exposure to the English language. This brought about the co-existence of two cultures in the child who was able to reconcile this apparent contradiction between the Yorùbá traditional religion and Christianity in his later years. This apparent biculturalism equally manifests in the eclectic nature of his writings.

Soyinka's return to Nigeria in 1960 on a Rockefeller Research Fellowship between 1961 and 1962 was very significant for him as a dramatist. With this he undertook intensive research of Nigerian tradition and culture. This research became very important in his development as a dramatist and in his understanding of the African world view. Katrak (6) observes that much of the materials gathered through this research were incorporated into his writings. Soyinka also observes the purpose of this research as he states that "A considerable dramatic activity exists already (in Nigeria) but it is chiefly European in content and imitative in conception. What is needed [...] is a fusion of the two enthusiasms" (qtd in Katrak 6-7). Thus, he fuses the two traditions in his English language drama in Nigeria. This is very explicit in The Road.

Soyinka's ultimate concern as a literary artist is his society. This is also very explicit in The Road. In an interview with Rex Colling, Soyinka avers that The Road is based on what he calls a personal intimacy which he developed with a certain aspect of the road: "It concerns the reality of death" and it is a very strange personal experience which developed out of his travels on the road (qtd in Dingome 32; emphasis in original). The play fictionalises the profession of driving and motor park touting that the road infrastructure brings to Yorùbáland, Nigeria. With the first inter-city road in Nigeria constructed between Ibadan and Oyo in 1913, a new profession of driving and touting emerged, especially in Lagos and the Yorùbá south-west of Nigeria. Ona (road) is a metaphor for progress in Yorùbá. The play therefore has progress as its factual thesis, which demonstrates a disastrous growth with society's worthless members in charge. Soyinka observed the drivers and touts in Lagos, Abeokuta, and Ibadan (his immediate environment) to design his play. Anyone who grew up in his time and had to travel on the vehicles plying the new roads experienced most of the events described in The Road (Dingome 31).

\section{The Road as an intertext}

One of the most common approaches to the study of literary texts is to find the intrinsic meaning of a text-literary interpretation. However, contemporary literary and cultural theories have challenged this 'usual' approach. This is due to the fact that works of literature are composed from systems, codes, and traditions established by previous works of literature. The implication of this is that a work of literature lacks independent meaning and to discover the total meaning of a text requires a network of textual relations. This is what gave rise to the term intertextuality (Allen l).

Intertextuality can be defined as the appropriation of earlier texts in the present texts by means of the author's selecting from texts, editing some parts of them, transforming, or even distorting them for his or her own use (Zengin 323). It is a poststructuralist and postmodernist critical theory which changed the concept of text, recognising it as an intertext owing to the interrelations of texts and texts' absorption of other texts (300). Its origin as a critical theory in the $20^{\text {th }}$ century can be traced to the works of Ferdinand de Saussure's structuralism which challenged the long-established belief and assumption that a literary work expresses its author's mind and personality and that it gives its reader an objective reality (305). Following the tenets of the structuralists, language is conventional and a language event or a text imitates language structures that have been conventionally used. The above implies that, by convention, a current text has its source in a previous linguistic event. Thus, intertextuality can be remotely traced to structuralism.

However, the ideas of Mikhail Bakhtin, a poststructuralist, gave birth to the intertextual theory as propounded by Julia Kristeva in 1966. According to Kristeva (35-6), "Bakhtin was one of the first to replace the static hewing of texts with a model where literary structure does not simply exist but is generated in relation to another structure" (emphasis in original). Bakhtin's insistence on otherness and his theory of dialogism and heteroglossia 
are the roots of Kristeva's theory. In her Revolution in Poetic Language (1984), Kristeva states that the term intertextuality means "the way in which one signifying practice is transposed into another" (qtd in Zengin 314). It "is a way of interpreting texts which focuses on the phenomenon of texts borrowing words and concepts from each other" (301). Another leading figure in the development of the intertextual theory is Barthes. His conception of intertextuality is presented by Eagleton thus:

All literary texts are woven out of other literary texts, not in the conventional sense that they bear traces of influence but in the more radical sense that every word, phrase or segment is a reworking of other writings which precedes or surrounds the individual work. There is no such thing as literary 'originality', no such thing as the 'first' literary work: all literature is 'intertextual'. (119)

The above calls forth the concept of intertext. An intertext is a text which has interrelations with other texts. An intertext cannot be said to be self-identical and autonomous in terms of form, language, and meaning. In fact, no text is an island; whenever a text comes into being it relates to previous texts and in its turn becomes the precursor of subsequent texts (Plett 17). Thus, it rejects the autonomy of the text as a pretext or a source text that is produced in a subsequent text or a target text. However, it should be noted that in intertextuality a pretext is not produced in its entirety, but only partially. It does not constitute an organic part of the target text but a removable alien element (9). In linguistics, intertextuality is synonymous with text incorporation which is defined as "the re-use of features or portions of existing text in the creation of a new text" (Adejare 124). It belongs to the textual meta-function of language which enables the language user to create cohesion within the text and the text's context of situation (Halliday 53). Such intertextual relations or text incorporations can be achieved through allusion, borrowing, parody, quotation, calques, plagiarism references, and translation, among others. For Kristeva, intertextual studies depend on the interpretation of a text's intertextual connections through which the text is created. It is an analysis of how the intertextual materials are transformed into the other text as well as its functional integration in the later text (qtd in Zengin 322).

An intertext has twofold coherence: an intratextual one which guarantees the immanent integrity of the text and the intertextual one which creates the structural relations between itself and other texts (Plett 5). The intertextual coherence makes a text eclectic. This eclectic reality manifests in the works of Soyinka and certainly adds to their difficulty and complexity and any study of his drama must confront its implications fully (Katrak 5). Adejare identifies two broad sources of intertextuality (text incorporation) in the works of Soyinka: from outside sources and from the writer's earlier text. In The Road Soyinka makes use of both sources. Yorùbá oral sacred texts and the Bible constitute the external pretexts or source texts from which Soyinka draws.

\section{Yorùbá sacred texts}

Soyinka makes extensive use of the Yorùbá oral sacred text as pretext in the creation of The Road. This is made possible by his in-depth knowledge of the Yorùbá oral tradition. One major source of incorporation in The Road is the Agẹmọ sacred text in Yorùbáland. It appears as the Agẹmọ preface poem prior to the opening of the play. The Agẹmọ is the deity believed by the Ijebus of Western Nigeria to be their supreme god. Agẹmọ, like the Egúngún, is a ritual of the dead. It embodies the ritual of the dead as practiced by the Ijebu people in Yorùbáland. The Agẹmọmasquerade parades through Ijebu towns during festivals. Only men are entitled to wear the mask and only certain families can participate in the ritual. One is appointed to be an Agẹmọ masquerade from childhood and is initiated through chants, certain sacrifices, and forms of religious purification. The Yorùbá people believe that one enters the shrine as flesh and emerges as the spirit of the dead. Hence Soyinka refers to it in a note to the producer as "a religious cult of flesh dissolution". Soyinka has described two Agẹmọ elements which he uses in The Road:

The thing about Agẹmọ that I use essentially in a sort of representative way is a masquerade. There are many forms of Agẹmọ festival. Some Agẹmọs are just like any other Egúngún masquerade. There are certain others who dance within mats rolled around their bodies. The human being, the form, is there (inside the mat) to symbolise the passage from flesh to nothingness [...] What had body, shape, before has become fibres. So, I use Agẹmọ in that sense as an illusion. (qtd in Katrak 63)

This Agẹmọ cult chant is spoken by the Alagẹmọ, a carrier of the Agẹmọ masquerade in the preface poem. It dominates the mood of the play. It is a symbol of death, the central message of the play. The essence of this spirit 
of Agẹmọ (death) is what Professor wants to find out in his quest for the Word. Murano, in whom the Word reposes, has experienced both life and death. He thus becomes the Agẹmọ spirit which Soyinka introduces into the main body of the play. His muteness (failure to reveal the meaning of the Word which reposes in him) accounts for the Yorùbá belief that death reveals itself only in one's death. This belief is made explicit in the ultimate death of Professor at the end of the play.

In the Preface Poem (The Road 150), the Alagẹmọ has been summoned from the other world:

I heard! I felt their reach

And heard my naming named.

The pit is there, the dagger fell right through

My roots have come out in the other world.

Make away.

and he begins to boast:

[...] Agẹmợ's hoops

Are pathways of the sun.

Rain-reeds unbend to me, Quench

The burn of cartwheels at my waste!

He threatens the future of the living community that nothing will prevent his anger from visiting them:

No sweat-beads droop beneath

The plough-wings of the hawk.

No beetle finds a hole between Agẹmợ's toes

The living community is the "sweat-beads" and the "beetle" while the Agẹmọ is the "plough-wings of the hawk", a predator on the living. He further elucidates the nature of his predatory visitation: that in which there will be no moment of relief:

$[\ldots]$ the Not-to-be

of the moistening moment of a breath $[\ldots]$

This spirit of death haunts all the characters in this play. The Preface Poem foreshadows the mystery and the numerous deaths in The Road.

The absence of a female character in this play has two implications. First, it reflects the social fact that women, to date, do not get involved in driving and touting business that The Road is concerned with. Women are generally passengers. Even though they are not barred from driving, the motor park job is for male dropouts. It would have been inappropriate in the fictional world if female characters had been involved in The Road. Secondly, since Agẹmọ is a male cult among the İjẹbú sub-group of the Yorùbá, the non-participation of women in the cult suggests the patriarchal structure of the Yorùbá society. This further reiterates the aptness of Yorùbá epistemology and ontology in relation to serious existential concepts like life and death. Since women are forbidden to see the AAgẹmọ masquerade, it becomes apparent that it is this spirit which controls the atmosphere of the play. A fuller understanding of The Road should consider the implication of the Alagẹmọ preface poem to the structure and preoccupation of the play.

The Yorùbá world view of the continuity between life and death is a major source text in the creation of The Road. It is the major force behind Professor's quest for the meaning of the Word which is interpreted by critics as a quest for the essence of life. This cyclic link between life and death is first projected in the Alagẹmọ poem:

The pit is there, the dagger fell right through

My roots have come out in the other world.

Make away [...]

\section{$[\ldots]$}

Pennant in the stream of time-Now,

Gone, and Here the Future

Make way. 
The line "My roots have come out in the other world" shows the link between life and death while the expression "Now, / Gone, and Here the Future" shows the link between the living, the dead, and the unborn as enshrined in the Yorùbá cosmology that death is not the end of life.

Professor's quest as guided by this Yorùbá world view is also presented in the opening scene of the play. He states thus: "I have sight and vision only for the Word and it may chance sometimes, that I missed my way among worldly humans" (158). Thus, his death at the end of the play shows the inability of humans to decipher the mystery of the cyclic nature of human life. This cyclic belief is also expressed in the character of Murano. He is dumb and he is the only one who has the ultimate meaning of life and death as he has been proclaimed sole guardian of the Word (186) and he "has one leg in each world" (187). This is also seen in his passage from the human to the divine during the drivers' festival as he wears the Egúngún mask. His lack of oral expressive power shows the futility of Professor's quest in particular and man's quest in general for the ultimate meaning of life and death. Furthermore, Professor's quest as enshrined in the Yorùbá cosmology makes him sleep in the graveyard as Samson says: "I cannot understand the man, going to sleep in the church yard with all that dead-body" and Professor says: "my bed is among the dead". Again, the graveyard is situated inside the church, a supposed place for the regeneration of life. This further suggests the mystery behind life and death.

The Ògún myth is another major oral text appropriated by Soyinka in the creation of The Road. In the Yorùbá cosmology, Ògún is a god with both creative and destructive powers. This dual nature of Ògún is represented in this text. Aspects of its creative power are seen in the modern technology that brought tarred roads into existence and the creation of motor vehicles made of iron and steel. Subsequently, this gave rise to its destructive influence that results in the numerous accidents and deaths that occur on the road in the play.

The Ògún festival as celebrated in the play is an aspect of the Yorùbá tradition. It is celebrated in many parts of Yorùbáland annually to appease Ògún to ward off imminent accidents on the road or in the farm or bush (Oderinde 6). The drivers responsible for the numerous accidents on the road are worshippers of Ògún. The drivers' festival in The Road is the Ogun festival. It is celebrated by them to ward off accidents on the road. The choice animal for the Ògún festival is a dog and it is offered on the road. Failure to do so will result in accidents through which Ògún will take humans as sacrifice. Thus, Samson tells Kotonu to:

Kill us a dog, kill us a dog. Kill us a dog before the hungry god lies in wait and makes a substitute of me [...] Dogs intestine looks messy to me he says [...] Ògún likes it that's all. It is his special meat. Serve Ògún his titbit so Ògún won't look us one day and say Ho ho you two boys look juicy tome. The one who won't give Ògún willingly will yield heavier meat by Ògún's designing. (The Road 188-9)

That Ògún is responsible for the accidents and the deaths on the road is underscored by the presence of the Ògún mask inside the Aksident Store and Kotonu sees it as his "humble quota to the harvest on the road".

Ritual is one of the wide variety of performances appropriated by Soyinka in The Road (Jeyifo 123). Ritual is an actor, a form of worship or communion or communication between one and one's object of worship (Adelowo 163). It goes with sacrifice which is an act of giving or offering an item to a god or a deity to show appreciation or to expect something in return. It is a very significant aspect of Yorùbá culture.

The above aspect of the Yorùbá tradition is brought into play by Soyinka in The Road. Samson states that "a dog is Ògun's meat" (165) and during the drivers' festival two of the mask followers are carrying a dog. In the absence of a dog, humans are killed by Ògún on the road as he states further: "Kill us a dog before the hungry god lies in wait and makes a substitute of me" (198). Thus, the numerous deaths on the road are ritual sacrifices to Ògún. Among the many sacrificial deaths in the play, Professor describes the death of the three people in an accident which he witnessed as "the latest offering of the Word" (188). He parodies the sacrificial death of Christ on the cross: "they died, all three of them crucified on rigid branches". Ritual festivity is also concentrated in the play. An instance of this can be seen in the flashback scene which re-enacts the accident during the drivers' festival when Murano, masked as an Egúngún spirit, was knocked down and presumed dead by Kotonu and Samson (Jeyifo 122).

Soyinka also draws from the aspect of the Yorùbá Egúngún mask as an oral source text. Egúngún is a masquerade or spirit of the ancestors in Yorùbá cosmology. The Egúngún mask is used extensively during the drivers' festival when Murano is masked as an ancestral Egúngún spirit. During the festival, the Egúngún followers are armed with whips. They chant, dance, and get involved in whipping context as is the norm in Yorùbá tradition. 
The Egúngún masquerade is believed to possess enormous powers by the Yorùbá people. When the Egúngún spirit experiences mystical possession, it performs the Egúngún ritual dance. This dance is the movement of transition as is observed in the Alagẹmọ poem. The dance and the mask are means of connection with the other world and this explains Professor's interest in Murano, the Egúngún mask carrier in whom the Word reposes (Dingome 39). The Egúngún must be treated in the normal ritualistic manner. Say Tokyo Kid's injunction that "you gorra do it proper" stems from the Yorùbá traditional belief in the dire consequences that result from the non-observance of proper ritual (Dingome 39). Thus, Professor's non-observance of the proper ritual by holding Murano-who has the spirit of the gods captive in him - results in his tragic death at the end of the play.

Incorporation of songs is common in Soyinka's plays. In The Road the songs range from the dirge to the thugs' war chant. In terms of their placement and preoccupation, these songs are structurally fit in the text. According to Jones (61), music is used suggestively and symbolically in The Road.

The first song, "Ona orunjin o eeeee" (It's a long road to heaven), was a popular highlife song in Nigeria in the fifties. It originated, probably, from the motor park touts (Adejare 125). In its original context, it was a warning song to drivers to beware of road accidents. Its incorporation into this text has changed the meaning. It now serves as a comment on the regular occurrence of road accidents caused by untrained drivers like Salubi who is waiting for Professor to forge a driving license for him. In this song, we are equally told that, no matter how skilful a driver may be, he is likely to die because of a road accident:

Esin baba Bandeleje l'odan

Won ogbefuno

Bandela's house galloped home a winner

but the race eluded him. (The Road 165)

In the thugs' war-chant "Eni ro'oro Ke Juba" (Who meets Oro and makes no obeisance), the thugs compare themselves to two Yorùbá gods, Oro and Ėșù. Oro is the Yorùbá spirit of punishment and Ėṣù is a trickster spirit. Thus, the song implies that anyone who refuses to yield to the whims and caprices of the thugs shall be severely crushed. This song is suited to the reign of violence and political terrorism symbolised by the thugs and Chief-in-Town.

The dirge for Kokol'ori is a folksong sung by the Yorùbá people during the burial of a prominent person or a hero who dies unexpectedly. It is a conclusion of the episode in which Samson gives a description of Kokol'ori. A truck pusher, father of Kotonu, he made love to his female passengers in lieu of monetary payments. He died in a motor accident. The song portrays Kokol'ori as a hero and his death as a tragedy:

Irise l'oganjoorunniki lo tije

Iri se 'oganjoorunni kilo s'orun

Irierun ta si mi l'Eșùikugb'omi tan

Irierun ta si mi l'aiyaotutueru mu mi

Iku se ni o, akonil'aiye lo

Eba mi kedun, Kokolorio [...]

It fogged certainly at noonday

The sun asked, what is this wonder?

The dew of drought settled on my feet

Death deprived us of rain

The dew of drought settled on my breast

And the chill of fear took me

Death has sinned against us

A man among men is gone [...] Kokol'ori (191)

Ironically, Kokol'ori's life never merits such a eulogistic dirge. He lived a life of adultery and left nothing for his children to inherit. Perhaps Soyinka is being humorous and satirical here rather than commenting on the society. Unlike Kokol'ori's dirge, Professor's praise song is a form of an Ijala poem, a folksong in Yorùbá oral poetry. According to Babalola, in Ijala poems the chanter presents a character of the subject of the poem in the form of a verbal salute to him or her and the portrait tends to be biased in favour of the person. However, some unpalatable truths may be mentioned in the poem. Although it is a praise poem, it is a direct attack on the attributes of Pro- 
fessor. The song refers to him as "a being like demon", a "coiled snake on mystery". He calls for this song after his long speech wherein he espouses himself as "a gleaner" and describes his favourite paths as "trickles among green fastness on which whole forests are broken up". This makes the content of the song appropriately suited to the character of Professor in the context of The Road.

Music and drumming are likewise used appropriately in structuring the mood of the play. In this play, drums perform both a social and a mystical function as used in the Yorùbá oral tradition. At the social level, Say Tokyo Kid summons his gang (the thugs) with a drum after Chief-in-Town's visit. Here the drum is used to announce to his partners in violence that another violent act is at hand. The drum is originally used as a symbol which suggests the unity of a tribe or a group in African society. Here the context has changed the meaning; it now suggests a sense of evil and disorder in the society. At the mystical level, the drum is used to revive Murano's dance and possession during the drivers' festival. The last scene of the play in which the rhythm of Agẹmọ is emerging from the bowels of the earth and the Egúngún begins to dance stands for possession. Thus, Agẹmọ music calls for the spirit of possession.

Apart from the instances discussed above, there is background music which initiates the appropriate mood in each of the episodes of the play. These songs range from church music to other organic music. These are instances of the text's absorption of other texts and they are all structurally and thematically relevant to the understanding of The Road. The Yorùbá belief in the existence of spirits in the external world is also incorporated into the text through Say Tokyo Kid. The Yorùbá people believe that inanimate beings like trees and plants have spirits that inhabit them and such spirits should be appeased. Say Tokyo Kid drives a timber lorry and he believes that there is a particular spirit that dwells in a particular timber. According to him, the reason why he has never been involved in an accident is because he knows how to appease the spirits that inhabit the logs which he carries in his lorry. Thus, he says: "There is a hundred spirits in a every guy of timber [...] You reckon a guy just goes and cuts down a guy of timber. You gorra do it proper man or you won't live to cut another" (171). To show his relationship with the spirits that inhabit the logs, he says: "[W]ell you tell me. Why ain't I cut and bruised like all these guys? Cause timber don't turn against her own son [...] I'm a son of timber" (172).

\section{The Bible}

The Bible is a major source, either of influence or inspiration, to writers. Soyinka's father, as noted earlier, was a Christian convert. This led to Soyinka's early engagement with the contents of the Bible. Scripture has a lot of traces in his novels, poems, and plays.

In The Road Soyinka creates the central character, Professor, as an ex-Sunday School teacher and a lay reader. This provides him with knowledge of the Bible, albeit imperfectly. Through him, Soyinka explores the scriptures to project the subjects at hand. Soyinka explores religious atrocities as he gives us an insight into Professor's old days in the church. He deliberately misinterprets the Bible and thus misinforms the children. He interprets the sign of the rainbow as a promise by God that he will not destroy the world with water and the palm frond worn on Palm Sundays as a sign that the world shall not perish from the thirst of palm- wine. The taking of palm wine in his bar is regarded as the Christian Holy Communion and he calls their evening songs hymns. These instances underscore the themes of religious hypocrisy and perversion which are major subjects in Soyinka's works.

The secular nature of the church which Soyinka projects is portrayed through the collapsing of the fence separating the church from the Aksident Store in the play. This is captured in the phrase "the day the wall of Jericho fell [...] down" (The Road 163) which has the book of Joshua, chapter 20 as the source text. Verse 5 reads: "[...] and the wall of the city shall fall down flat" while verse 20 says "[...] and the wall fell down flat [...]". ${ }^{1}$ This fall of the wall separating the church, a religious institution, and the roadside shack, a citadel of corruption, decay, and secularity, underscores the concerns of the church with externals and secularity. The central message projected here is the collapse of the church as a religious institution.

Professor's quest for the Word has been given various interpretations. One could trace the origin of the Word to scripture. The Bible is the sole repository of the Word and the church its guidance as it is recorded in the book of St. John: "In the beginning was the Word and the Word was with God and the Word was God [...] And the Word was made flesh, and dwelt among us [...]" (John 1:1 and 14; emphasis added).

Perhaps it is this revelation that "the Word was made flesh, and dwelt among us" that spurs Professor on in his quest. Or, as Ogude observes, the lectern bearing the Word on the bronze may refer to the Bible itself on the 
lectern (62). In focusing on religious hypocrisy, Soyinka incorporates the Word from the Bible and makes Professor's quest for it destructive and revolutionary. He affirms that anything is possible in the quest. In rejection of St. John's incarnation, he says: "The Word may be found in companion not to life but to death".

Soyinka also incorporates scriptural language through Professor. This use of scriptural language is an attempt by Professor to assume a Christ-like control over his people to enhance his exploitation and domination. He parodies Christ's answer to the Pharisees when asked why he eats with sinners and tax collectors. Christ answered: "Those who are well have no need of a Physician but those who are sick [...] For I came not to call the righteous, but sinners" (Matthew 9:12-3). Similarly, Professor says: "My task is to keep company with the fallen. Only the fallen have need for restitution" (220).

Again, he parodies the death of Christ on the cross in the description of the death of three persons in an accident which he witnessed: "They died, all three of them crucified on rigid branches". The "three of them" is an allusion to Christ and the two thieves who were crucified with him while "rigid branches" refers to the crosses. The implication of this is that their death is a sacrifice to Ogun, the god of the road.

In presenting the picture of poverty and disease which is endemic in the society, he draws on the metaphor of friendship between David and Jonathan in the first book of Samuel. Samson tells Salubi that: "Your body and lice day like David and Jonathan" (185). In the Bible the relationship between David and Jonathan is that of love and intimate friendship: "The soul of Jonathan was knit to the soul of David, and David loved him as his own soul [...] Then Jonathan made a covenant with David because he loved him as his own soul" (I Sam. 18:1-3).

Semantically, the above extracts are parallel. Structurally, they are also parallel with the relationship between Salubi and disease and Jonathan and David. It implies that Salubi and lice are intimate friends and that they have one soul just like Jonathan and David.

With an informed knowledge of the scripture, Soyinka captures the divisions in the society. It is a materialistic society with a high sense of perversion: the best option open to this society is bribery and corruption. Thus, Salubi parodies the Lord's Prayer in an attempt to receive a bribe from Samson, the assumed millionaire. He says: "Give us this day our daily bribe" (155) in place of the scriptural "Give us this day our daily bread" (Matthew 6:11), substituting the lexical item bribe for bread. Thus, the emphasis in the society is placed on bribery which comes in the form of tips and drops. However, the above instances are reshaped quotations from the Bible with a new meaning to suit the context of the play. This does not imply that the playwright has a shallow knowledge of the scripture. Rather, it shows his artistic and creative ingenuity and his deep knowledge of the scripture. This is explicit in his ability to manipulate texts from the Bible to fit his present context in order to project his messages.

\section{Other external sources}

Soyinka appropriates texts from other external sources to project aspects of the thematic preoccupation of the play. One of these is the lexical item "BEND" which has the lexicon of a road traffic sign as the source text. It is used by Soyinka to convey to the readers that the accidents are caused deliberately. This is seen in the description of Professor in the stage direction as he enters the scene:

Professor is a tall figure in Victorian outfit - tails, top-hat etc., all thread-bare and shiny at the lapels from much ironing. He carries four enormous bundles of newspaper and a fifth paper odds and ends impaled on a metal rod stuck in a wooden rest. A chair-stick hangs from one elbow, and the other arm clutches a road sign bearing a squiggle and the one word, 'BEND' (156-7; emphasis in original)

The fact that the lexical item BEND is made prominent graphologically shows its importance. As a traffic sign on the road, BEND is meant to caution road users and Professor's removal of it and his taking it to his Aksident Store as he enters the scene of the play shows his intentional and wilful act to cause accidents on the road. This further projects the themes of man's inhumanity and bestiality. And to show how passionate he is in protecting the removed road sign, Soyinka further states thus: [Suddenly suspicious, he clutches the road-sign possessively]. "If this is a trick I swear they shan't take it from me. If my eyes were deluded and my body led here by spells I shall not surrender the fruit of my vigil. No one can take it from me! (157; emphasis in original)"

In the above extract, it and the fruit of my vigil refer to the road sign. To Professor, taking the road sign from him implies taking his source of livelihood because accidents that occur due to a lack of signs on the road help him to stock his store. Referring to the road sign as the fruit of his vigil implies that he removed it at night to avoid being seen. This underscores his wickedness as a gleaner. 
Soyinka also alludes to the Burma war (216), the Remembrance Day memorial (216), and the King George Cross (217) and Victoria Cross (217) to drive home the theme of racial prejudice and injustice. Sarcastically, Soyinka condemns wars when he alludes to the Burma war: "It is peaceful to fight a war which one does not understand, to kill human beings who never seduced your wife or poisoned your water. Sapele to Burma-that was a long way for a quarrel" (216).

In the above, Sapele stands for Africa, while Burma stands for all the foreign wars taken part in by Africans. Through this, Soyinka condemns the involvement of Africans in wars as enforced by white people. Africans were forced to fight in wars that did not concern them. In particular, it is the Burma war that endows Sergeant Burma with his predatory nature. Like Professor, the gleaner, he has no compassion for humanity. Remembrance Day is a memorial in Commonwealth countries instituted after the end of the First World War to honour the soldiers who died in the war. All Sergeant Burma was awarded during one of the memorial church services after the war was a long service ribbon. The King George Cross is a United Kingdom and Commonwealth medal while the Victoria Cross was introduced by Queen Victoria to honour acts of valour in the Crimean War. The reward for Sergeant Burma's involvement in the Burma war that neither concerned him nor his nation was for him not to be honoured. The authorities refused to honour Sergeant Burma with the King George Cross because he was black. Even when the general cabled that he should be awarded the Victoria Cross the colonial government in Africa refused out of fear of his becoming a political agitator on his return. He thus sums up his disappointment in Nigerian pidgin: "Haba! Justice no dey for white man world" (Ah! There is no justice in white men's world).

\section{Borrowing from prior texts}

In the works of a writer, it is possible to identify some recurrent features. In most cases this might be consciously done by the writer. In The Road, Soyinka consciously incorporates from his other texts. The problem of date of composition and publication makes it difficult to determine the pretext(s). However, there are traces of the re-use of some materials either in whole or modified in The Road.

One subject that has continued to fascinate Soyinka in his writings is the never-ending carnage on Nigerian roads. An untold number of travellers have lost their lives in motor accidents and, as such, death on the road has become a recurring intertextual thematic focus in Soyinka's works. Specifically, a group of poems designated "Poems of the road" in Idanre and Other Poems are concerned with death on the road. Among the poems, "In Memory of Segun Awolowo" is a poem to a young friend killed in such an accident. "Death in the Dawn" is also concerned with the same subject. It is based on an experience which Soyinka had in Lagos. A white cockerel flew out of dusk and smashed against his windscreen. A mile further he came across a motor accident and a freshly smashed man (Idanre 10). The same subject of death on the road becomes the subject of one of his most fascinating plays, The Road. Like the poems above, it is inspired by Soyinka's awareness of deadly road realities in Nigeria. These works dwell on the rich harvest that Ògun regularly reaps on his domain, the road, as a result of numerous automobile crashes. These deaths are attributed to Ògún who is celebrated in Yorùbá folklore as the pathfinder. "In Memory of Segun Awolowo" condemns Ògún as a "scrap-iron dealer". The sacrifice of the "dawn's lone trumpeter" in "Death in the Dawn" is futile to Ògún and in The Road Samson tells us that "The one who won't give Ògún willingly will yield heavier meat by Ògún's design".

Of interest are the identifiable similar linguistic structures in describing these accident scenes. Soyinka describes the death of the "dawn's lone trumpeter" as:

$[\ldots]$ cascades.

Of white feather-flakes [...] (Idanre 10)

In "Death in the Dawn" in The Interpreters he describes the death of Sekoni thus:

Showers of laminated glass around, him his head one

fastness of blood and wet earth (The Interpreters 155)

And in describing an accident scene which Professor witnessed in The Road, a similar pattern is sustained:

And showers of crystal flying or broken

souls. (The Road 159) 
The above extracts are similar semantically. Also, similar imagery is sustained in describing the different scenes. More striking is the similarity between the last two texts. The language is the same: "Showers of laminated glass" means the same thing as "showers of crystals" and "broken souls" is a reduction of "one fastness of blood and wet earth". It is obvious from this that one of the texts is a source for the other.

In "Idanre" what appears to be an assertive statement of the fate of wayfarers becomes a prayer in "Death in the Dawn" and The Road:

Fated lives rides on wheels of death

when The Road waits, famished ("Idanre" lines 94-5);

May you never walk

When the road waits, famished ("Death in the Dawn" lines 23-4)

and

May you never walk when the road

waits, famished. (The Road 199)

The semantic and linguistic similarities in the above extracts are explicit enough. The only difference lies in the structure of the first text. However, the same phrase and structure is repeated - the same pattern of punctuation: a comma before "famished". No doubt, this is a case of conscious incorporation by the playwright to underscore the theme of accidents and deaths on the road.

Another identifiable source from Soyinka's own text is from The Interpreters. Chief Winsala with his "deep alcoholic amorousness" is described by Mathias in pidgin in this manner: "He and him bottle dey like David and Goliath" (The Interpreters 74). Similarly, in The Road, the disease-stricken Salubi with his mouth that "stinks like night-soil lorry" is referred to by Samson thus: "Your body and lice dey like David and Jonathan" (The Road 185). These utterances are made in pidgin and the references are to the same personalities in the Bible. This use of "David and Goliath" by Mathias is a reflection of his shallow knowledge of the scripture; he intends to say, "David and Jonathan". The relationship drawn is that of friendship as illustrated by David and Jonathan in I Samuel Chapter 18. Similarly, Winsala's and Salubi's souls are knitted to drink and disease, respectively. The scripture is the source text for these two extracts. The above examples are instances of intertextual deviations.

There is also a similar context of the usage of the Word in The Interpreters and one context of usage in The Road. These are cases in which the Word is used as a curse or swear word. Bandele uses the Word in this manner: "old and immutable as the royal mother of Benin throne, old and cruel as the Ogboni in conclave pronouncing the Word. I hope you all live to bury your daughters" (The Interpreters 251). Professor damns Salubi in a similar context:

May the elusive Word crack your bones

in a hundred splinters! (The Road 184)

or,

May your tongue of deception be rotted in pestilence from the enigma of the Inviolate Word. (The Road 184)

or

Get out of my sight, and the Word follow you as you leave my threshold. (The Road 184)

Izevbaye (38) identifies these usages as a divine power manifesting itself in potent utterances. This recalls the Ogboni's use of the earth cult as a means of gaining power and transmitting it verbally.

That these features are identifiable in a similar context shows that Soyinka incorporates into a text features from another text. This source is secondary. However, identifying the initial text may be difficult, but the ability of the reader to identify a similar usage of a text is important. It facilitates understanding of a text in a similar context. This goes a long way to enhance the understanding of a writer's thematic preoccupation and worldview. 


\section{Conclusion}

This paper has shown the extent to which Soyinka relies on the Yorùbá sacred texts, the Bible, and his own already-existing texts in the creation of The Road. This reliance on external sources should not be seen as plagiarism, but rather as a mark of versatility and creative ingenuity on the side of the playwright in as much as some of the texts incorporated are not just borrowing but instances of creative incorporation. Intertextuality has helped Soyinka to achieve thematic significance in this play. This is in view of the fact that, through these intertextual sources, the play is able to reflect the complex society which he mirrors and foreground the various themes of the play.

\section{Notes}

1. All citations from the Bible are from the Revised Standard Version, 1901.

\section{Works Cited}

Adejare, Oluwole. Language and Style in Soyinka: A Textlinguistic Study of a Literary Idiolect. Heinemann, 1992.

Adelowo, Dada E. "Rituals, Symbolism and Symbols in Yorùbá Religious Thought." AJT vol. 4, no. 1, 1990, pp. 162-173.

Allen, Graham. Intertextuality: The New Critical Idiom. Routledge, 2000.

Babalola, Adeboye. Ijala: a form of oral poetry in Nigeria. Lagos Federal Ministry of Information, 1963.

Dingome, Jeanne. "Soyinka's The Road as Ritual Drama." Kunapipi vol. 2, no. 1, 1980, pp. 30-4l. https://ro.uow.edu.au/kunapipi/ vol2/issl/6.

Eagleton, Terry. Literary Theory: An Introduction. Minnesota U P, 2008.

Halliday, M. A. K. An Introduction to Functional Grammar. Arnold, 1985.

Izevbaye, Dan S. "Language and Meaning in Soyinka's The Road." African Literature Today: Drama in Africa vol. 8, 1976, pp. 52-6.

Jeyifo, Biodu. Wole Soyinka: Politics Poetics and Postcolonialism. Cambridge U P, 2004

Jones, Eldred Durosimi. The Writing of Wole Soyinka. Heinemann, 1973.

Kristeva, Julia. "Word, Dialogue and Novel." The Kristeva Reader, edited by Toril Moi. Columbia U P, 1986, pp. 34-61.

Katrak, Ketu H. Wole Soyinka and Modern Tragedy: A Study of Dramatic Theory and Practice. Greenwood, 1986.

Maledo, Richard Oliseyenum. "Structure and Meaning in Soyinka's Works: A Case Study of The Road." Journal of the Literary Society of Nigeria vol. 3, no. 1, 2010, pp. 130-40.

Oderinde, Olatunde Abosede. "The Lore of Religious Festivals among the Yorùbá and its Social Relevance." Lumina vol. 22 , no. 2, 2011, pp.1-12.

Ogude, Steve E. "Professor, The Word and the Problem of Meaning in Wole Soyinka's The Road." Journal of Literary Society of Nigeria vol. 1, 1981, pp. 56-66.

Ògúnba, Oyin. Movement of Transition: A Study of the Plays of Wole Soyinka. Ibadan U P, 1975.

Plett, Heinrich F. “Intertextualities.” Intertextuality, edited by Heinrich F. Plett. Walter de Gruyter, 1991, pp. 3-29.

Pouille, Adrien. "Ambivalent Relation with the Divine in Wole Soyinka's The Road." Ufahamu: A Journal of African Studies vol. 39, no. 2, 2016, pp. 37-58. https://escholarship.org/uc/item/2m20r630.

Shamsi, Marzieh, Sohila Faghfori \& Seyed Ali Booryazadeh. "Ritual/Carnival Performance in Wole Soyinka's The Road." Theory and Practice in Language Studies vol. 5, no. 9, 2015, pp. 1935-39. DOI: http://dx.doi.org/10.17507/tpls.0509.24.

Soyinka, Wole. Wole Soyinka Collected Plays 1. Oxford U P, 1973 Idanre and Other Poems. Metheun, 1967.

The Interpreters. Fontana, 1972.

Myth, Literature and the African World. Cambridge U P, 1976.

Zengin, Mevlude. "An Introduction to Intertextuality as a Literary Theory: Definitions, Axioms and the Originators." Pamukkale University Journal of Social Sciences Institute vol. 25, no. 1, 2016, pp. 299-326. 